\title{
Justice Perception Has Effects On Organizational Outcomes: Do Managers Care About Fairness?
}

\author{
Vandna Talwar \\ Pursuing Ph.D. from Indian Institute of Technology Delhi, India
}

\begin{abstract}
This research study examines the effects of justice perception within the organization from the perspective of managers. Managerial perception in terms of justice perception and organizational outcomes has been studied across managers of 10 organizations $(N=100)$. Correlation and regression analysis reveals the high organizational commitment and decreased turnover rates due to managerial factors like; Communication, Trust, and Reliability.
\end{abstract}

Keywords: Managerial Actions, Justice perception, Organizational outcomes.

\section{Introduction}

Organizations in present times can be considered as a minituarized version of community and justice and their pervasive role of organizations' has enhanced the role of justice within organizations (Hosseinzadeh and Naseri, 2009). Researchers in the past have discussed the role of organizational justice in effective management as it is said to influence employee sentiments. In order to achieve employee satisfaction, commitment and decrease the overall turnover rate, leadership within the organization is equally important (Fatt et al, 2012; Mello, 2005). Therefore, it is important to determine if the managers actually care about ensuring justice perception, as their actions will not only benefit the employee but the organization as well as a whole. Previous researches have pointed out the role of managers in improvement of performance level, decrease in absenteeism, lowered employee turnover rate which in turn lead to organizational growth and development (Jahromi et al, 2009; Javadin et al, 2009). Therefore, the present research study is being conducted from the perspective of managers within New Delhi, to determine their perception and the role of their behavior on the overall justice perception among the employees leading to organizational outcomes. Present study aims to achieve this understanding through a statistical test to determine the role of managerial initiatives on organizational outcomes.

Research objectives

- To evaluate organizational outcomes because of justice perception.

- To examine the role of the managers in justice perception

Research question

- What are the actual outcomes of an organization due to justice perception among employees?

- What is the actual role of the managers in justice perception?

\section{Introduction to justice perception}

\section{Literature Review}

Justice perception is the perception of employees of an organization about the fairness of the work environment which includes the pay structure and organizational processes followed by the company. In an organizational setting, justice perception can be of three types: Distributive, procedural and interactional. Distributive justice explains the perception of employees with respect to payments and benefits provided by the company and procedural justice includes employees perceptions about organizational processes(Erat et al, 2012). Interactional justice is the treatment received by an employee as elucidation of the information given or decisions taken (Usmani \& Jamal, 2013).

Employees who perceive high of the fairness of a company are likely to stay longer with the company. Also, they are more committed and thus more effective at work. On the other side employees with lower fairness perception of the company are less likely to show sincerity at work leading to counterproductive attitude. Such employees may leave the company early. Thus, justice perception can be considered as an important parameter for an organizational effectiveness as it individually affects its working employee who are responsible for carrying out different organizational tasks. The outcomes of the organizations work is thus affected by the perception of its employees about the fairness of employment such that a positive view builds trust in them and thus, they deliver as per the expectations or goals of the organization(Seok \& Chiew, 2013). 


\section{Organizational outcomes due to lack of justice perception}

Justice perception in an organization plays an important role. There are many studies which try to investigate the impact of justice perception on organizational outcome, such as performance, employee behavior, job satisfaction, employee commitment, productivity and decrease in turnover intention etc (Kakakhel, Ali, Rahman, \& Ahsan, 2014).

According to study conducted by Moorman in year 1991, "allocation and distribution of resources will have a direct impact on several work related motives, organizational outcomes such as performance, as well as attitude behavior." organizational commitment it can define as a degree to which people identify with the organization that employs them (Wagner and Holleneck 2005; Simons \& Roberson, 2003). When employees of the organization are treated as fairly, then the outcomes are very high and employees are loyal and committed towards the organization and ultimately which gives results in a decrease in turnover rate.

Role of Manager in Justice Perception and organizational Outcomes

Several studies have been conducted in the past which have focused on the role of managers in justice perception and organizational outcomes. Based on these studies the researcher has identified some factors likewise, communication, trust, reliability etc.

Communication: Communication plays an important role in justice perception (Scott, Colquitt, \& Zapata-Phelan, 2007). As better communication can enhance the justice perception, reduces uncertainty and ensures positive employee reactions towards manager (Brockner \& Wiesenfield, 1993; Hopkins \& Weathington 2006). Gopinath and Becker, 2000 in his research found that communication helped employees and managers to understand the events relating to a divestiture increased employee perception regarding justice (Schminke, Ambrose and Noel, 1997). According to Bass \& Avolio, 1984 with the help of efficient communication, managers can build rapport, display consideration and concern, which could directly enhance employee trust and organizational commitments.

Trust: According to the study conducted by the SAKS in the year 2006, "As in any relationship, trust is among the essential trait that keeps commitment strong. The employer-employee relationship is no different. Relationships evolve over time into trusting, loyal and mutual commitments as long as the parties abide by certain rules of the exchange, the Trust is highly valued and can only be built up over time, but can be lost quickly.” (Luo, 2005)

Reliability: Role of transformational leadership has been studied and four components have been identified; i.e. idealized influence, inspirational motivation, intellectual stimulation and individualized consideration (Bass, 1985). All these factors when considered together aid the overall reliability of the employee on the leader/manager. Role of transformation leadership on personal outcomes i.e. reliability of the justice perception has been reported by a number of researchers (Boerner, Eisenbeiss, \& Griesser, 2007; Zhu, Chew, \& Spangler, 2005; Jorg \& Schyns, 2004).

\section{Conceptual Framework}

Based on the findings of the literature survey, the researcher developed conceptual framework for the study, which has been presented below.

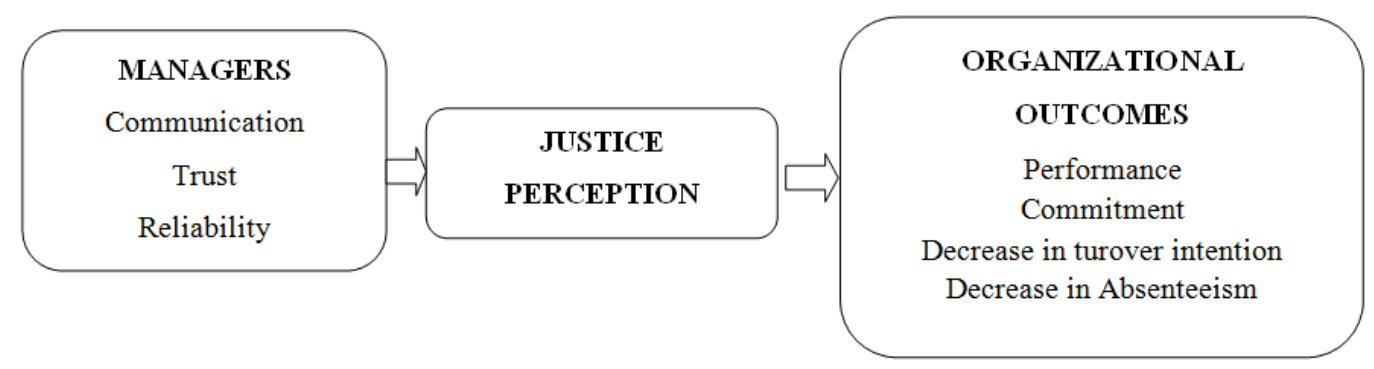

Figure 1: Conceptual Framework

Source: Compiled by the Researcher

\section{Hypothesis for the research}

Null Hypothesis: Managerial actions do not impact justice perception

Alternative Hypothesis: Managerial actions impact justice perception

Null Hypothesis: Justice Perception due to managers does not impact organizational outcomes Alternative Hypothesis: Justice Perception due to Managers impacts organizational outcomes 


\section{Research philosophy}

\section{Research Methodology}

According to the need of the current research paper, positivism has been chosen. This philosophy has been beneficial for the researcher as it helps to understand the current scenario and accordingly derive the conclusion which discusses the major factors associated with the justice perception and organizational outcomes.

\section{Research design}

The research design followed in the current research is descriptive as it will derive the aspects that are related to the involvement of justice perception in the firm. Along with this the role of the mangers in the relation to those justices are also described in a clear manner.

\section{Research approach}

The following study involves a deductive approach as all the theory related to the justice perception are evaluated and integrated so that the actual effect of these perceptions on the performance of the organization can be evaluated properly.

\section{Data collection}

As per the current research, both primary and secondary data are collected by the researcher. Primary research data was collected from 100 managers across 10 organizations mostly small and medium scale organizations operational in different sectors in New Delhi, India. Each of the participating organization was approached with a cover letter which defined the aim and objectives of the study. Once the approval was seeked, close-ended questionnaire were emailed to them and the filled responses were received within 15 days of submission. In order to supplement the primary data, researcher also collected secondary data from different sources i.e. journals, books, research articles, etc.

\section{Reliability and validity of methods}

The data are collected from authenticated and credible sources for secondary data based research. In order to determine the reliability of data collected, Cronbach alpha test was conducted using SPSS 19.0 which reflected a value of 0.871 for measuring instrument responses.

\section{Data analysis}

The responses collected were first processed and coded in MS Excel, from where the data was imported to SPSS 19.0. The responses were then subjected to correlation and regression analysis in order to test the hypotheses proposed in the study. Results of hypothesis testing are presented in the next section.

\section{Demographic Profile of the Respondents}

\section{Result And Discussion}

Descriptive analysis conducted to determine the demographic profile of the participating respondents is reflected in Table 1 given below. While 60\% of the managers were aged between 31-40 years age group, only $10 \%$ managers were aged between 25-30 years. Remaining 30\% of the respondents were aged between 41-50 years. In terms of gender, the distribution was somewhat equal i.e. 55\% respondents were males and $45 \%$ respondents were females.

\begin{tabular}{|l|l|l|l|l|l|}
\hline Variable & \multicolumn{2}{l|}{ Age (In year) } & \multicolumn{2}{l|}{ Gender } \\
\cline { 1 - 5 } Statistics & \multicolumn{2}{|l|}{ Male } & Female \\
\hline & $26-30$ years & $31-40$ years & $41-50$ years & Male & $55 \%$ \\
\hline Percent & $10 \%$ & $60 \%$ & $30 \%$ & $55 \%$ & \\
\hline
\end{tabular}

Table 1: Descriptive Statistics of Demographic Profile of the Respondents

Source: SPSS 19.0

\section{Hypothesis for the research}

Null Hypothesis: Managerial actions do not impact justice perception

Alternative Hypothesis: Managerial actions impact justice perception

In order to prove the hypothesis, the research conducted correlation among the managerial factors i.e. communication, trust and reliability and their impact of justice perception. The respondents were asked if these variables according to them impacts impact justice perception or not. Results of Correlation analysis revealed that, according to most of the researchers, these factors have an impact on the justice perception among employees. As can be seen in the Table 2 given below: Communication and Relaibility play a more important 
role among towards justice perception as are significant at $98 \%$ confidence interval with $\mathrm{p}$ value of .751 and .712 respectively, while trust was depicted significant at $95 \%$ significant level with $p$ value of 0.632 .

\begin{tabular}{|l|l|l|}
\hline \multicolumn{2}{|l|}{ Correlations } \\
\hline \multirow{4}{*}{ Managerial Communication } & Pearson Correlation & $.751^{* *}$ \\
\cline { 2 - 3 } & Sig. (2-tailed) & .001 \\
\cline { 2 - 3 } & $\mathrm{N}$ & 100 \\
\hline \multirow{3}{*}{ Managerial Trust } & Pearson Correlation & $.632^{*}$ \\
\cline { 2 - 3 } & Sig. (2-tailed) & .021 \\
\cline { 2 - 3 } & $\mathrm{N}$ & 100 \\
\hline \multirow{3}{*}{ Managerial Reliability } & Pearson Correlation & $.712^{* *}$ \\
\cline { 2 - 3 } & Sig. (2-tailed) & .002 \\
\cline { 2 - 3 } & $\mathrm{N}$ & 100 \\
\hline
\end{tabular}

Table 2: Correlation between Justice Perception and Managerial actions

Based on the results, therefore, the researcher rejects the null hypothesis and accepts the alternative hypothesis.

Null Hypothesis: Justice Perception due to managers does not impact organizational outcomes Alternative Hypothesis: Justice Perception due to Managers impacts organizational outcomes

The impact of justice perception due to managerial actions was studied with its effect on the organizational outcome. The responses gathered from the managers across 10 organizations indicated that high justice perception has been found to contribute towards high performance $(\alpha=.003$, p-value $=.624)$, high commitment $(\alpha=.002, \mathrm{p}$-value $=.765)$, decrease in turnover intention $(\alpha=.000, \mathrm{p}$-value $=.871)$ significant at $98 \%$ confidence interval. Decrease in absenteeism $(\alpha=0.043$, p-value $=.619)$ was also reported to have correlation with justice perception.

\begin{tabular}{|l|l|l|}
\hline \multicolumn{2}{|l|}{ Correlations } & $\begin{array}{l}\text { Justice Perception due to } \\
\text { managerial actions }\end{array}$ \\
\hline \multirow{4}{*}{ High Performance } & Pearson Correlation & $.624^{* *}$ \\
\cline { 2 - 3 } & Sig. (2-tailed) & .003 \\
\cline { 2 - 3 } & $\mathrm{N}$ & 100 \\
\hline \multirow{4}{*}{ High Commitment } & Pearson Correlation & $.765^{* *}$ \\
\cline { 2 - 3 } & Sig. (2-tailed) & .002 \\
\cline { 2 - 3 } & $\mathrm{N}$ & 100 \\
\hline \multirow{3}{*}{ Decrease in turover intention } & Pearson Correlation & $.871^{* *}$ \\
\cline { 2 - 3 } & Sig. (2-tailed) & .000 \\
\cline { 2 - 3 } & $\mathrm{N}$ & 100 \\
\hline \multirow{3}{*}{ Decrease in Absenteeism } & Pearson Correlation & $.619^{*}$ \\
\cline { 2 - 3 } & Sig. (2-tailed) & .043 \\
\cline { 2 - 3 } & $\mathrm{N}$ & 100 \\
\hline
\end{tabular}

Table 3: Correlation between Justice Perception and Organizational Outcomes

Based on the responses, therefore the researcher concludes that there is strong correlation between justice perception of employees based on managerial actions and organizational commitment. Therefore, we reject the null hypothesis and accept the alternative hypothesis.

\section{Conclusion}

The paper studied the justice perception of employee within companies with respect to the different actions taken by managers. The literature review attempted to understand the concept of justice perception and its types. It also included understanding of the role of managers in forming the justice perception of employees. Various actions that were required by managers for this were discussed. Moreover, it also included expected outcomes from the employees. These outcomes were the result of good performance with respect to different parameters that were to be tested if they were affected by the justice perception of the employees.

The main aim of this research was to understand if the managers could affect the outcome of a company by impacting the justice perception of employees. In order to find this, the goal was subdivided into 
two objectives that were to understand if managers could affect the justice perception and if justice perception could impact the outcomes delivered by the employees of the company.

Based on the hypothesis testing, the importance of managerial actions has been proved to affect the organizational outcomes in positive manner. Each dimension of managerial actions in terms of communication, trust and reliability on the manager leads to high performance, high commitment, decrease in turnover intention and decrease in organizational commitment. The present study has been conducted from the perspective of manager, however, in future the study can be conducted from the perspective of employees, at a larger scale.

\section{References}

[1]. Bass, B. M. (1985). Leadership and performance beyond expectations. New York: The Free Press.

[2]. Boerner, S., Eisenbeiss, S. A., \& Griesser, D. (2007). Follower behavior and organizational performance: The impact of transformational leaders. Journal of Leadership \& Organizational Studies, 13(3), 15-26.

[3]. Erat, S., Erdil, O., \& Kitapci, H. (2012). The Impact of Organizational Support and Justice Perceptio on Commitment and Intention to Quit: An Empirical Study of Turkish State universities. Journal of Global Strategic Management, 11, 132-142. Retrieved from http://www.isma.info/uploads/files/132-the-impact-of-organizational-support-and-justice-perception-on-commitment-and-intentionto-quit-an-empirical-study-on-turkish-state-universities.pdf

[4]. Fatt C. K., Khin S. E. V., \& Heng N. T., (2010) The Impact of Organizational Justice on Employee's Job Satisfaction The Malaysian Companies Perspectives. American Journal of Economics and Business Administration, 2(1), 56-63.

[5]. Hopkins, S. M., \& Weathington, B. L. (2006). The relationships between justice perceptions, trust, and employee attitudes in a downsized organization. The Journal of Psychology, 140, 477-498. doi:10.3200/JRLP.140.5.477-498

[6]. Hosseinzadeh A., \& Naseri M., (2009). Organizational Justice. Tadbir, 18(190), 18-23.

[7]. Jahromi S. A. S., Salehi M., \& Imani J., (2009) Relationship between organizational justice and organizational commitment with job satisfaction among exceptional schools teachers of Bandar Abbas Journal of Educational Sciences, , 2(5), 7-33.

[8]. Jorg, F., \& Schyns, B. (2004). Is similarity in leadership related to organizational outcomes? The case of transformational leadership. Journal of Leadership \& Organizational Studies, 10(4), 92-102.

[9]. Kakakhel, S. J., Ali, N., Rahman, W., \& Ahsan, A. (2014). Impact of Human Resource Management Practices on Employees' outcomes (Empirical Evidence from Public Sector Universities of Malakand Division, KPK, Pakistan). Life Science Journal, 11(4), 68-77. Retrieved from http://www.lifesciencesite.com/lsj/life1104s/009_23330life1104s14_68_77.pdf

[10]. Luo, Y. (2005). How Important are shared perceptions of Procedural Justice in Cooperative Alliances? Academy of Management Journal. doi:10.5465/AMJ.2005.17843946.

[11]. Mello J. A. (2005) Strategic Human Resource Management, Thomson/South-Western, 2nd ed, 213-320.

[12]. Schminke M., Ambrose, M. L., \& Noel, T. W. (1997). The Effect of Ethical Frameworks on Perceptions of Oganizational Justice. Academy of Management Journal. doi:10.2307/256932

[13]. Scott, B. A., Colquitt, J. A., \& Zapata-Phelan, C. P. (2007). Justice as a dependent variable: subordinate charisma as a predictor of interpersonal and informational justice perceptions. The Journal of Applied Psychology, 92, 1597-1609. doi:10.1037/00219010.92.6.1597

[14]. Seok, C. B., \& Chiew, T. C. (2013). Trust, Trustworthiness and Justice Perception Toward the Head of Department. Global Journal of Arts Humanities and Social Sciences, 1(1), 20-29. Retrieved from http://www.eajournals.org/wp-content/uploads/TRUSTTRUSTWORTHINESS-AND-JUSTICE-PERCEPTION-TOWARD-THE-HEAD-OF-DEPARTMENT.pdf

[15]. Simons, T., \& Roberson, Q. (2003). Why managers should care about fairness: the effects of aggregate justice perceptions on organizational outcomes. The Journal of Applied Psychology, 88, 432-443. doi:10.1037/0021-9010.88.3.432

[16]. Seyed Javadin S. R., Faraahi M. M., \& Taheri A. G., (2009). How different dimensions of organizational justice affect the different dimensions of job and organizational satisfaction Journal of Business Management, 1(1), 55-70.

[17]. Usmani, S., \& Jamal, S. (2013). Impact of Distributive Justice, Procedural Justice, Interactional Justice, Temporal Justice, Spatial Justice on Job Satisfaction of Banking Employees. Integrative Business \& Economics, 2(1). Retrieved from http://sibresearch.org/uploads/2/7/9/9/2799227/riber_k13-103_351-383.pdf.

[18]. Zhu, W., Chew, I. K. H., \& Spangler, W. D. (2005). CEO transformational leadership and organizational outcomes: The mediating role of human-capital-enhancing human resource management. Leadership Quarterly, 16(1), 39-52.

Appendix:

Questionnaire: Please tick whatever is appropriate for the statements

1. Effectiveness of Managerial communication leads to justice perception

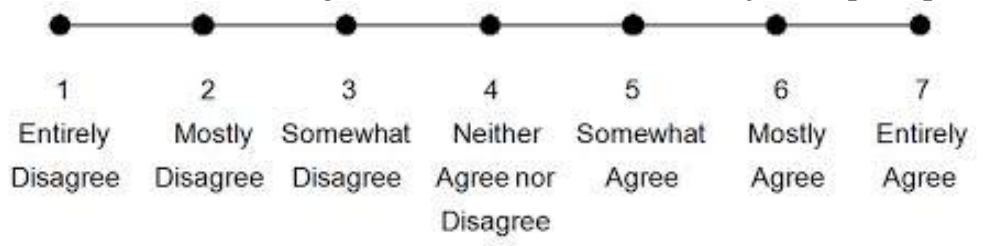

2. Effectiveness of Managerial trust leads to justice perception

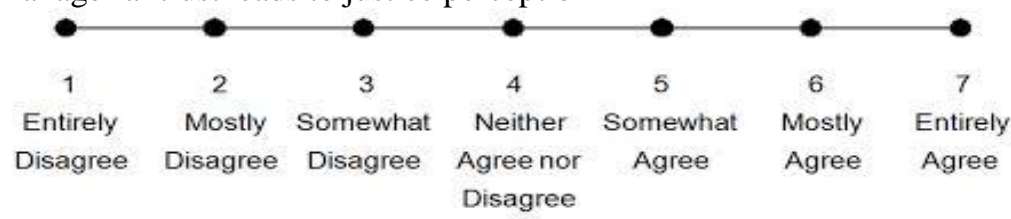


3. Effectiveness of Managerial reliability leads to justice perception

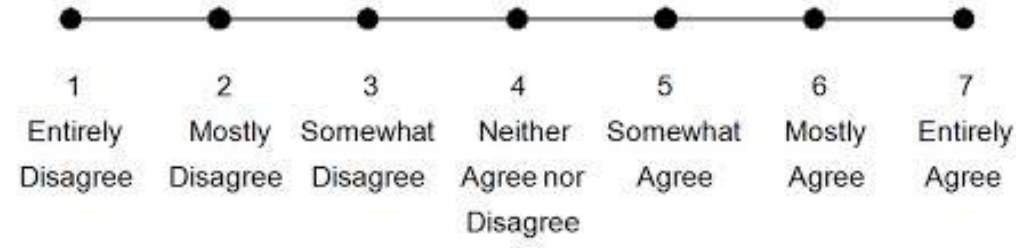

4. Justice perception due to managerial actions leads to high performance among employees.

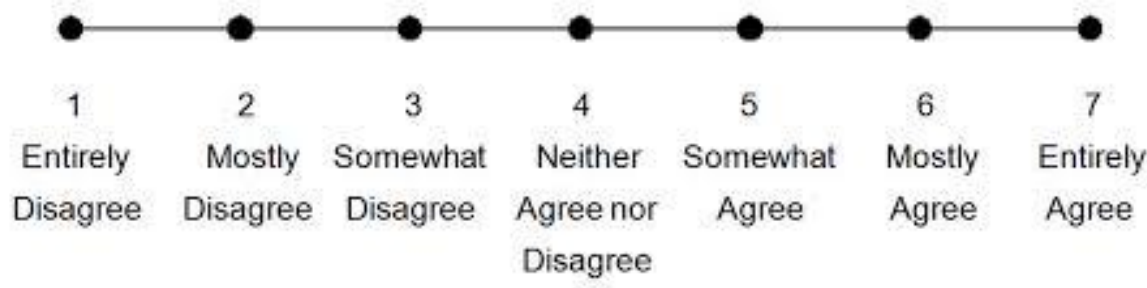

5. Justice perception due to managerial actions leads to low absenteeism among employees.

$\begin{array}{ccccccc}1 & 2 & 3 & 4 & 5 & 6 & 7 \\ \text { Entirely } & \text { Mostly } & \text { Somewhat } & \text { Neither } & \text { Somewhat } & \text { Mostly } & \text { Entirely } \\ \text { Disagree } & \text { Disagree } & \text { Disagree } & \begin{array}{c}\text { Agreenor } \\ \text { Disagree }\end{array} & \text { Agree } & \text { Agree } & \text { Agree }\end{array}$

6. Justice perception due to managerial actions leads to decrease in turnover rate among employees

$\begin{array}{ccccccc}1 & 2 & 3 & 5 & 6 & 7 \\ \text { Entirely } & \text { Mostly } & \text { Somewhat } & \text { Neither } & \text { Somewhat } & \text { Mostly } & \text { Entirely } \\ \text { Disagree } & \text { Disagree } & \text { Disagree } & \begin{array}{c}\text { Agreenor } \\ \text { Disagree }\end{array} & \text { Agree } & \text { Agree } & \text { Agree } \\ & & & & \end{array}$

7. Justice perception due to managerial actions leads to high commitment among employees

$\begin{array}{ccccccc}1 & 2 & 3 & 4 & 5 & 6 & 7 \\ \text { Entirely } & \text { Mostly } & \text { Somewhat } & \text { Neither } & \text { Somewhat } & \text { Mostly } & \text { Entirely } \\ \text { Disagree } & \text { Disagree } & \text { Disagree } & \begin{array}{c}\text { Agreenor } \\ \text { Disagree }\end{array} & \text { Agree } & \text { Agree } & \text { Agree }\end{array}$

